\title{
Evaluation of Physicochemical and DPPH· Cleaning Activity of Ultrasonic Assisted Extraction of Polysaccharide from Leonurus japonicus
}

\author{
MINGJUN YANG ${ }^{1 *}$, AVWENAGBIKU O MERCY ${ }^{1,2}$, NEHIKHARE EFEHI ${ }^{1,3}$, \\ MUSSIFULINA VENERA ${ }^{1}$, XIAOFENG LIU ${ }^{1 *}$, ABDOL GHAFFAR EBADI ${ }^{4}$, \\ MOHSEN TOUGHANI ${ }^{5}$ \\ ${ }^{1}$ School of Life Science and Engineering, Lanzhou University of Technology, Lanzhou 730050, China \\ ${ }^{2}$ School of Agriculture and Agricultural Technology, Federal University of Technology, Akure, 340252, Nigeria \\ ${ }^{3}$ Faculty of Life Science, University of Benin, Nigeria \\ ${ }^{4}$ Department of Agriculture, Jouybar Branch, Islamic Azad University, Jouybar, Iran \\ ${ }^{5}$ Department of Fishery, Islamic Azad University Babol Branch, Babol, Iran
}

\begin{abstract}
Leonurus japonicus is rich in bioactive compounds especially polysaccharide. Single factors test and response surface methodology were used to study the optimum conditions for ultrasonic assisted extraction of polysaccharide from L. japonicus, and its physiochemical and DPPH scavenging activities also were evaluated. The optimal conditions as underpinned by this paper is as follow: extraction temperature of $70{ }^{\circ} \mathrm{C}$, extraction time of $50 \mathrm{~min}$ and extraction power of $210 \mathrm{~W}$. The polysaccharide of L. japonicus was shown to be a non-reducing sugar and to exhibit DPPH scavenging activity to an extent. The polysaccharide structures were studied using SEM, AFM, and FT-IR. It showed L. japonicus polysaccharide had been having more than one chains which were branched and entangled with each other. and existed a broad band wavelength of 2925.64, 1635.06, 1539.7, 1046.73, and $477.86 \mathrm{~cm}^{-1}$. The study indicated that L. japonicus may have a beneficial use to the medical and food industries.
\end{abstract}

Keywords: Leonurus japonicus, Polysaccharide, Ultrasonic-assisted extraction, Response surface methodology (RSM), DPPH scavenging activity

\section{Introduction}

Leonurus japonicus is employed in the treatment of several ailments among the 50 fundamental Chinese medicine. Referred to as motherwort "Yimucao" in Chinese. Some of its use in Chinese herbal medicine include edema dispel, regulation of menstrual disorder, diuretics and invigorating blood circulation [1]. The active components of L. japonicus as conforming to modern pharmacological studies such as bioactive polysaccharides, have been reported to exhibit some pharmacological properties such as cardio protective, anticancer, antioxidant, analgesic and neuroprotective, antibacterial as well as have effect on women uterus [2]. The leaves, which is capable of producing essential oils has been reported to have some antioxidant properties too. In the cosmetics industry, it is currently being used as facial masks or ointments and also in food products, accompanied with other components to treat skin disease as well as help in activation of blood circulation [3]. Presently, the replacement of synthetic antioxidant with naturally occurring antioxidant is increasing due to the side effects associated with synthetic antioxidant such as increased risk of cancer [4-15].

This has led to increased interest in finding natural elements in foods and medicinal plants with bioactivities. Polysaccharides obtained from medicinal plants are an important health care product because they function as anti-tumor [16], antioxidant [17], and anticoagulant [18].

*email: xiaofengl@bk.ru,yangmj@lut.cn 
The extraction methods employed in the extraction of polysaccharides play huge role in the bioactivities as well as the yield of polysaccharide. Response Surface Methodology (RSM) is a collection of mathematical and statistical techniques used for improving and development of extraction process [19-23]. It is also useful in evaluating the effects of several independent variables not necessarily using predetermined relationship on the system responses. The application of RSM in design optimization enables reduction in experimental trail numbers. In this study, ultrasonic assisted extraction was used to extract polysaccharide from the whole plant including roots, stems, leaves and flowers of $L$. japonicus due to its efficiency and low cost. RSM was used to optimize the extraction process. The objective was to determine the physicochemical and DPPH scavenging antioxidant capacity of the polysaccharide extracted from L. japonicus.

\section{Materials and methods}

\subsection{Preparation of $L$. japonicus sample}

Sample consisting of dried roots, stems, leaves, flowers of L. japonicus was purchased from Lanzhou, Gansu province. It was air-dried and milled using a cyclotech mill. It was passed through a 40-mesh sieve to give a fine powder. Sample was packed, sealed and stored at room temperature for other analysis.

\subsection{Ultrasonic-assisted extraction of polysaccharide from $L$. japonicus sample}

The extraction of polysaccharide from $L$. japonicus performed using ultrasonic assisted treatment was carried out in an ultrasonic processor (KQ-250DB, Kunshan Ultrasonic Instrument Co., Ltd., Jiangsu, China). The extraction temperature, extraction time, and ultrasonic power were fixed at ranges of $60-80^{\circ} \mathrm{C}, 40-60 \mathrm{~min}$ and $180-240 \mathrm{~W}$, respectively. The solid-liquid ratio was constant at 1:15. After extraction, it was centrifuged at $3000 \mathrm{rpm}$ for $15 \mathrm{~min}$; the supernatant was collected and stored at $4^{\circ} \mathrm{C}$ for further analysis.

\subsection{Determination of polysaccharide yield from $L$. japonicus}

The polysaccharide concentration was determined using the phenol-sulfuric acid method [24,25]. The extract was analyzed and its optical density measured at $485 \mathrm{~nm}\left(\mathrm{OD}_{485}\right)$. Polysaccharide concentration was calculated using the linear regression equation $\left(Y=0.0569 x-0.0005, \mathrm{R}^{2}=0.9973\right)$ derived from the standard curve with vertical coordinate denoting $\mathrm{OD}_{485}$ and horizontal coordinate the concentration of glucose $(\mathrm{g} / \mathrm{mL})$, respectively. Polysaccharide yield was calculated according to the formula below:

$$
\text { Yield of polysaccharide }(\%)=\frac{C \times N \times V}{W \times 1000} \times 100 \%
$$

where $C$ represents the concentration of the polysaccharide calculated by the calibrated regression equation $(\mathrm{mg} / \mathrm{mL})$; $\mathrm{N}$ was the dilution factor; $\mathrm{V}$ was the total volume of extraction solution $(\mathrm{mL})$ and $\mathrm{W}$ as the weight of the dried L. japonicus sample (g).

\subsection{Experimental design and statistical analysis}

The single-factor experimentation with three factors including extraction power (A), extraction time (B) and extraction temperature (C) was used to evaluate the effect on the yield of L. japonicus polysaccharide.

According to the single-factor experimentation, three preliminary factors, extraction power (A), extraction time (B) and extraction temperature (C) was obtained. To determine the best combination of extraction factors for the optimization of L. japonicus, a Box-Behnken design (BBD) with three independent variables at three levels was performed. The key parameters based on single-factor were determined to be extraction power, extraction time and extraction temperature. The Box-Behnken 
design and response value used for the model development is displayed in Table 1. As described by Montgometry [26], five central points in the experimental design accounted for the method repeatability. 17 random trails were carried out and the quadratic polynomial model employed was as follows;

$$
Y=\beta_{\mathrm{o}}+\beta_{1} A+\beta_{2} B+\beta_{3} C+\beta_{11} A^{2}+\beta_{22} B^{2}+\beta_{33} C^{2}+\beta_{12} A B+\beta_{13} A C+\beta_{23} B C
$$

where $\mathrm{Y}$ denotes the dependent variable, $\beta_{\mathrm{o}}$ represents the constant coefficient of the model which is the intercept. $\left(\beta_{1}, \beta_{2}, \beta_{3}\right),\left(\beta_{11}, \beta_{22}, \beta_{33}\right)$ and $\left(\beta_{12}, \beta_{13}, \beta_{23}\right)$ denotes the coefficient for linear, quadratic and interaction terms, respectively. $\mathrm{A}, \mathrm{B}$, and $\mathrm{C}$ are the coded independent variables. The regression coefficient $\mathrm{R}^{2}$ was used in determining the fitness of the quadratic polynomial model while the significance of the regression coefficient was examined using the F-value and P-value.

Table 1. Box-Behnken design Independent variables and levels used

\begin{tabular}{|c|c|c|c|}
\hline Levels & $\begin{array}{l}\text { Extraction power } \\
\text { (A) (Watt.) }\end{array}$ & $\begin{array}{l}\text { Extraction time } \\
(B) \quad(\mathrm{min})\end{array}$ & $\begin{array}{l}\text { Extraction Temp. } \\
\begin{array}{ll}(\mathrm{C}) & \left({ }^{\circ} \mathrm{C}\right)\end{array}\end{array}$ \\
\hline-1 & 180 & 40 & 60 \\
\hline 0 & 210 & 50 & 70 \\
\hline 1 & 240 & 60 & 80 \\
\hline
\end{tabular}

\subsection{Analysis of physicochemical properties}

The physicochemical properties of the polysaccharide determined were as follows: colour test was done according to Ge et al. [27], solubility as described by Armas et al. [28], Coomassie Brilliant Blue method [29], Carbazole reaction by Bitter and Muir [30], $\mathrm{FeCl}_{3}$ reaction as described by Zhou [31], Molish test following Mohamed [32], and phenol test using the sulfuric method [24].

\subsection{Analysis of DPPH scavenging activity}

The DPPH free radical scavenging activity was determined according to the method described below, ascorbic acid $(\mathrm{Vc})$ was used as a reference standard for comparison. The sample of the polysaccharide was dissolved in methanol to get a series of solutions with different concentrations (20$100 \mu \mathrm{g} / \mathrm{mL})$. About $1.5 \mathrm{~mL}$ of methanol DPPH radical solution $(0.004 \% \mathrm{w} / \mathrm{v})$ and $1.0 \mathrm{~mL}$ of the polysaccharide sample were mixed vigorously and incubated at room temperature for $30 \mathrm{~min}$ in the dark. Absorbance of the mixture was measured at $517 \mathrm{~nm}$. Blank solution contain all reagent except plant extract. The scavenging activity $(\%)$ was then calculated by using the following equation.

$$
\text { Scavenging activity of DPPH }(\%)=\frac{A 0-A 1}{A 1} \times 100 \%
$$

where $A_{0}$ was the absorbance of the control and $A_{1}$ was the absorbance of the extract and standard.

\subsection{Structural analysis of $L$. japonicus polysaccharide}

The chemical structure of L. japonicus was determined by Fourier transform infrared spectroscopy (FT-IR) at a resolution of $0.09 \mathrm{~cm}$ in the frequency range of $400-4000 \mathrm{~cm}^{-1}$ [33] while the surface microstructure and morphological characteristics were observed with Atomic force microscopy (AFM) and Scanning electron microscopy (SEM) (JSM-5600LV, American Kevex Company, America).

\subsection{Statistical analysis}

Origin Pro software package 8.5 (Origin Lab Corp) and Design Expert software Version 8.0.5 (Stat-Ease Inc.) were used to conduct the statistical analysis. All data were represented as mean value of three replicate determinant with differences considered to be significant when $\mathrm{p}<0.05$. 
Table 2. The yield of polysaccharide by Box-Behnken design

\begin{tabular}{ccccc}
\hline No. & $\begin{array}{c}\text { A: Extraction power } \\
(\mathrm{W})\end{array}$ & $\begin{array}{c}\text { B: Extraction Duration } \\
(\mathrm{min})\end{array}$ & $\begin{array}{c}\text { C: Extraction temp. } \\
\left({ }^{\circ} \mathrm{C}\right)\end{array}$ & $\begin{array}{c}\text { Yield } \\
(\%)\end{array}$ \\
\hline 1 & 180 & 40 & 70 & 9.56 \\
2 & 240 & 40 & 70 & 9.38 \\
3 & 180 & 60 & 70 & 9.32 \\
4 & 240 & 60 & 70 & 9.27 \\
5 & 180 & 50 & 60 & 9.93 \\
6 & 240 & 50 & 60 & 9.63 \\
7 & 180 & 50 & 80 & 9.24 \\
8 & 240 & 50 & 80 & 9.15 \\
9 & 210 & 40 & 60 & 10.1 \\
10 & 210 & 60 & 60 & 9.8 \\
11 & 210 & 40 & 80 & 9.51 \\
12 & 210 & 60 & 80 & 9.24 \\
13 & 210 & 50 & 70 & 11.58 \\
14 & 210 & 50 & 70 & 11.6 \\
15 & 210 & 50 & 70 & 11.61 \\
16 & 210 & 50 & 70 & 11.57 \\
17 & 210 & 50 & 70 & 11.64 \\
\hline
\end{tabular}

\section{Results and discussions}

\subsection{Single factor experiment}

\subsubsection{Effect of different time on the extraction yield of $L$. japonicus polysaccharide}

The effect of the different time $(30,40,50$, and $60 \mathrm{~min})$ on the yield of polysaccharide was examined with the other extraction parameters such as temperature, power and solid-liquid ratio set at $70^{\circ} \mathrm{C}, 210$ watt and 1:15 respectively. The duration of time employed in the extraction of polysaccharide play a vital role in the yield of polysaccharide. As illustrated in Fig. 1a, at 30min, the yield of polysaccharide was $10.6 \%$ which continually increase with maximum yield of $11.5 \%$ at 50 min. There was a drastic decreased in the yield of polysaccharide when time was set at $60 \mathrm{~min}$. This could be due to longer extraction time which could result to lower yield of polysaccharide [34].

\subsubsection{Effect of different temperature on the extraction yield of $L$. japonicus polysaccharide}

The effect of extraction temperature $\left(40,50,60,70\right.$ and $\left.80^{\circ} \mathrm{C}\right)$ on the yield of L. japonicus polysaccharide was illustrated by Fig. $1 \mathrm{~b}$ with other parameters set as follows: extraction time (50 min), extraction power (210 watt) and solid-liquid ratio (1:15). The figure showed that there was a graduate increased in extraction yield as the temperature was increased. The maximum yield of polysaccharide $(11.64 \%)$ was detected at $70^{\circ} \mathrm{C}$ which a sharp declined as soon at the temperature attained $80^{\circ} \mathrm{C}$. Although, some studies had suggested that a higher temperature benefit the solubility and extraction yield of polysaccharide [35] but when the temperature was above certain degree, it could decrease the polysaccharide yield of some plant materials as shown in Figure $2 \mathrm{~b}$. So, the temperature range of $60-80^{\circ} \mathrm{C}$ was adopted as the optimal for the $\mathrm{BBD}$ experiment.

\subsubsection{Effect of extraction power on the yield of $\mathbf{L}$. japonicus polysaccharide}

Different extraction power was set at 120,180,210, 240 and $300 \mathrm{~W}$ respectively in order to investigate the influence of power on the yield of L. japonicus polysaccharide with other parameters set as follows: extraction temperature $\left(70{ }^{\circ} \mathrm{C}\right)$, extraction time $(50 \mathrm{~min})$ and solid-liquid ratio $(1: 15)$. Plant molecules solubility could be increased with ultrasonic power as a result of the destruction of intra and inter-molecular bonds and the increment of contact efficiency between hydrophilic groups 
and extraction solvents [36]. The yield of polysaccharide continually increased until it attained its maximum yield (11.54\%) at was 210 watt and then declined. Higher ultrasonic power can result in the degradation of the extracted polysaccharide which can bring about lower yield [37-43].
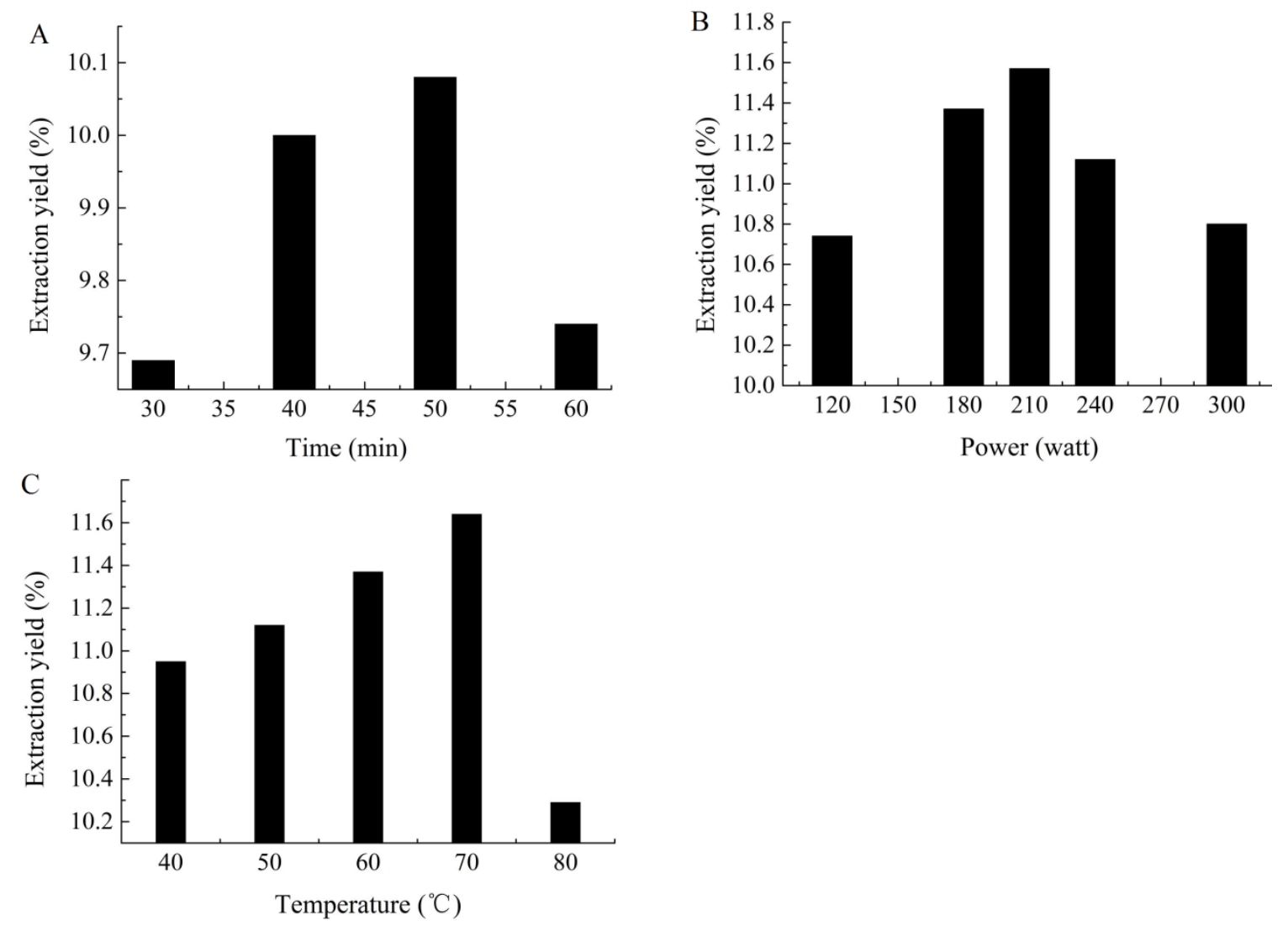

Figure 1. Effect of time (A), power (B), and temperature (C) on the extraction yield of L. japonicus polysaccharide

\subsection{Fit of model and statistical analysis}

BBD was used to optimize and investigate three independent variables extraction power (factor 1), extraction time (factor 2) and extraction temperature (factor 3) in order to determine the most suitable combination of extraction factors. Table 2 showed the response value of yield with the design matrix obtained by BBD. It can be observed that the yield of polysaccharide ranged from $9.24-11.64 \%$ with maximum yield at $70{ }^{\circ} \mathrm{C}, 210 \mathrm{~W}$ and $50 \mathrm{~min}$. The experiment error was determined using Trial No. 13 17 in Table 2. The model for the predicted yield of polysaccharide (Y) according to the multiple regression analysis on the experimental data was represented by the following quadratic polynomial equation:

$$
\begin{gathered}
\mathrm{Y}=-110.32375+0.53800 A+0.98175 B+1.21325 C+1.0833 E-004 A B+1.75000 E \\
-004 A C+7.50000 E-005 B C-1.32917 E \\
-003 A^{2}-0.010212 B^{2}-9.16250 E-003 C^{2}
\end{gathered}
$$

Analysis of variance (ANOVA) was used to carry out the statistical test as shown Table 3. Table 3 displayed the fitted quadratic polynomial model of extraction for L. japonicus polysaccharide. The model F-value of 1037.46 implied that the model was significant. There was only a $0.01 \%$ chance that this 'Model F-Value' could occur due to noise. Values of 'Prob $>$ F' less than 0.0500 indicated model terms were significant. In this case, the independent variables $(\mathrm{A}, \mathrm{B}, \mathrm{C})$, the interaction term (AC) and the quadratic term coefficient $\left(\mathrm{A}^{2}, \mathrm{~B}^{2}\right.$, and $\left.\mathrm{C}^{2}\right)$ were significant model terms. Values greater than 0.1000 indicated the model terms were significant. The "Lack of Fit F-value" of 4.13 implied that the 
Lack of Fit was not significantly relative to the pure error. There was a $10.20 \%$ chance that a "Lack of Fit F-value" this large could occur due to noise. A Non-significant lack of fit indicated that the model

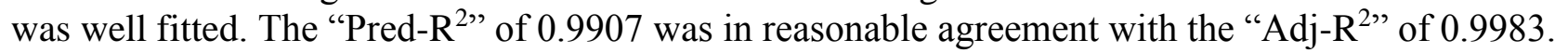

\subsection{Analysis of RSM}

In order to assess the effects of variables and their interactions on the yield of polysaccharide, a tridimensional (3D) surface plot and 2D contour plot (Figure $2 \mathrm{~A}-\mathrm{C}$ ) were used to illustrate the interaction effects of the variables on responses. To determine the effect of the three variables (extraction temperature, extraction duration and power) on the yield of polysaccharide, one variable within the experimental range remained adjusted at central point which reflected the effect of the other two variables.

Table 3. ANOVA for Response Surface Quadratic Model (Analysis of variance table)

\begin{tabular}{|c|c|c|c|c|c|c|c|}
\hline Source & $\mathrm{SS}^{\mathrm{a}}$ & $\mathrm{CE}^{\mathrm{b}}$ & $\mathrm{DF}^{\mathrm{c}}$ & $\mathrm{MS}^{\mathrm{d}}$ & $\mathrm{SE}^{\mathrm{e}}$ & F Value & P Value \\
\hline Model & 16.41 & 11.60 & 9 & 1.82 & 0.019 & 1037.46 & $<0.0001 \mathrm{~s}$ \\
\hline A & 0.048 & -0.077 & 1 & 0.048 & 0.015 & 27.35 & 0.0012 \\
\hline B & 0.11 & -0.11 & 1 & 0.11 & 0.015 & 60.21 & 0.0001 \\
\hline $\mathrm{C}$ & 0.67 & -0.29 & 1 & 0.67 & 0.015 & 382.89 & $<0.001$ \\
\hline $\mathrm{AB}$ & $4.225 \mathrm{E}-003$ & 0.032 & 1 & 4.224E-003 & 0.021 & 2.40 & 0.1649 \\
\hline $\mathrm{AC}$ & 0.011 & 0.052 & 1 & 0.011025 & 0.021 & 6.27 & 0.0407 \\
\hline $\mathrm{BC}$ & $2.250 \mathrm{E}-004$ & $7.500 \mathrm{E}-003$ & 1 & $2.250 \mathrm{E}-004$ & 0.021 & 0.13 & 0.7310 \\
\hline $\mathrm{A}^{2}$ & 6.025322 & -1.20 & 1 & 6.03 & 0.020 & 3429.05 & $<0.0001$ \\
\hline $\mathrm{B}^{2}$ & 4.39 & -1.02 & 1 & 4.39 & 0.020 & 2499.16 & $<0.0001$ \\
\hline $\mathrm{C}^{2}$ & 3.53 & 10.92 & 1 & 3.58 & 0.020 & 2011.67 & $<0.0001$ \\
\hline Residual & 0.012 & & 7 & $1.757 \mathrm{E}-003$ & & & \\
\hline Lack of fit & $9.300 \mathrm{E}-003$ & & 3 & $3.100 \mathrm{E}-003$ & & 4.13 & $0.1020 \mathrm{~ns}$ \\
\hline Pure error & $3.000 \mathrm{E}-003$ & & 4 & $7.500 \mathrm{E}-004$ & & & \\
\hline Cor. total & 16.42 & & 16 & & & & \\
\hline Std. Dev. & 0.042 & & & $\mathrm{R}^{2}$ & 0.9993 & & \\
\hline Mean & 10.13 & & & Adj- $R^{2}$ & 0.9983 & & \\
\hline C.V. (\%) & 0.41 & & & Pred- $\mathrm{R}^{2}$ & 0.9907 & & \\
\hline PRESS & 0.15 & & & Adequate Precision & 75.506 & & \\
\hline
\end{tabular}

s: significant; ns: not significant, ${ }^{\mathrm{a}}$ Sums of squares, ${ }^{\mathrm{b}}$ Coefficient estimate, ${ }^{\mathrm{c}}$ Degree of freedom,

${ }^{\mathrm{d}}$ Mean square, ${ }^{\mathrm{e}}$ Standard error.

The 3D plot and 2 contour plots as shown in Figure 2A displayed the effect of extraction duration and extraction temperature on the yield of polysaccharide. As the time increased, the yield significantly increased. At $50 \mathrm{~min}$ and $70^{\circ} \mathrm{C}$, the yield attained its maximum yield and exponentially decreased. As a result of the decline in yield after $50 \mathrm{~min}$ and $70^{\circ} \mathrm{C}, 50 \mathrm{~min}$ extraction time and a temperature of $70^{\circ} \mathrm{C}$ was selected as the central point for the RSM analysis.

Figure $2 \mathrm{~B}$ showed the interaction between extraction power $(\mathrm{A})$ and extraction temperature $(\mathrm{C})$ on the yield of polysaccharide. From the plot, increase in extraction temperature brought about increase in polysaccharide yield with maximum yield of $11.64 \%$ at $70^{\circ} \mathrm{C}$ and power at $210 \mathrm{~W}$, then it declined. It can be observed from the 3D plot that the minimum yield at $9.15 \%$ resulted from the effect of temperature at $70^{\circ} \mathrm{C}$ and power of $210 \mathrm{~W}$ as reflected on the contour plot. Due to the decrease in polysaccharide yield after $210 \mathrm{~W}$, a power of $210 \mathrm{~W}$ was adopted as the central point of the RSM analysis. The relationship between the extraction duration and power as indicated in Figure $2 \mathrm{C}$ with power at $210 \mathrm{~W}$ and time at 50 min resulted in the maximum yield of the polysaccharide. 
A moderately high temperature and shorter time had been reported to be attributed to higher yield using ultrasonic equipment. Some studies $[44,45]$ reported that ultrasound assisted extraction had a shorter extraction time $(52 \mathrm{~min})$ and a lower temperature $\left(70{ }^{\circ} \mathrm{C}\right)$ as compared to traditional extraction with longer time and temperature. The higher yield of polysaccharide which was accounted for at 50 min and $70{ }^{\circ} \mathrm{C}$ had been underpinned by this statement.

The three 3D surface plots were almost similar and all reflected that the maximum yield of the polysaccharide was attained at power of $210 \mathrm{~W}$, extraction duration of $50 \mathrm{~min}$ and extraction temperature of $70{ }^{\circ} \mathrm{C}$. It can also be concluded that a slight change in any of the parameters (power, time, temperature) could bring about a considerable change on the yield of polysaccharide.

A
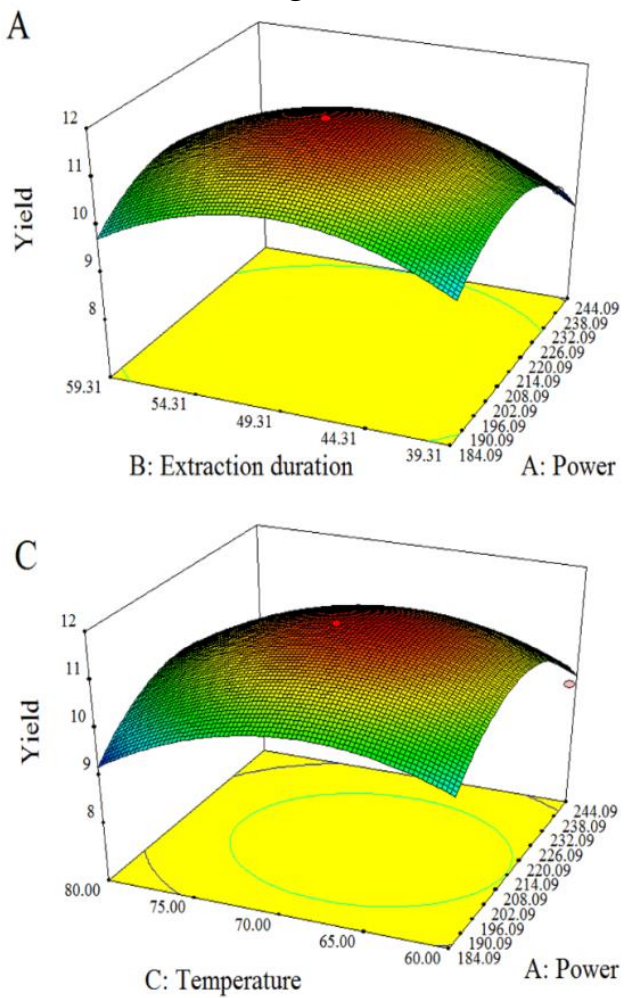

E

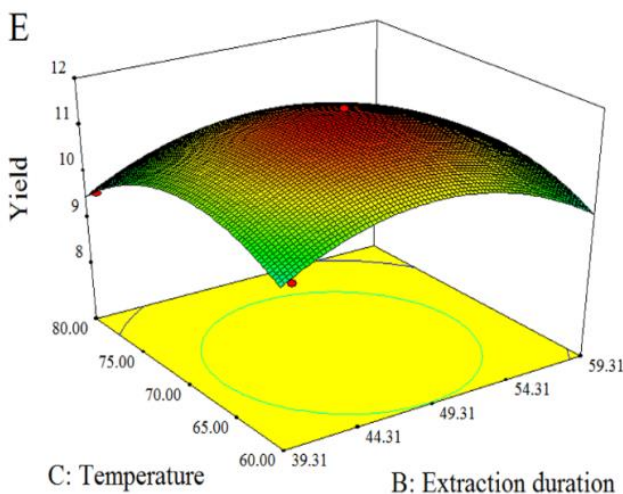

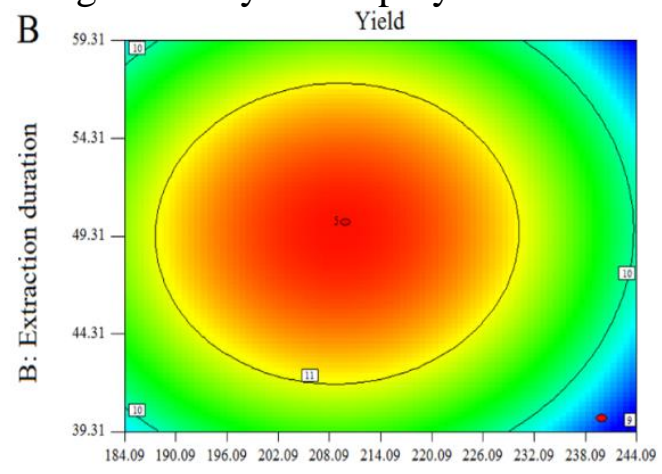

A: Power

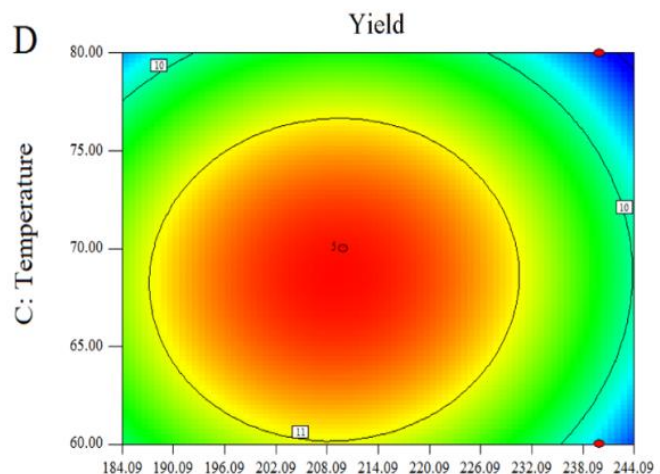

A: Power

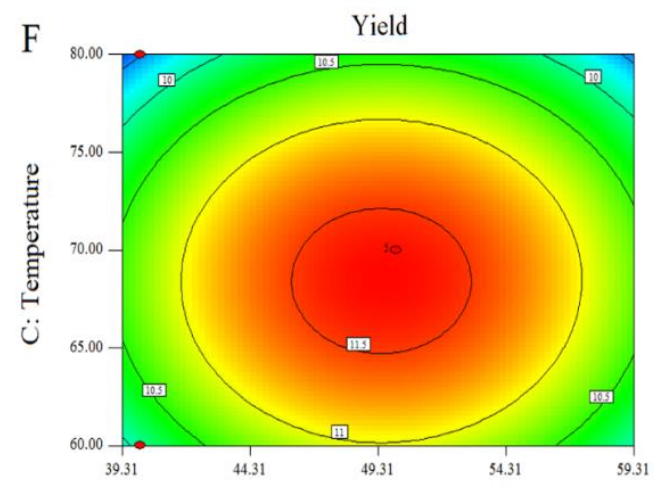

B: Extraction duration

Figure 2. Response surface 3D surface plot and 2D contour plot illustrating the effect of different parameters (power, extraction duration and temperature) on the yield (\%) of L. japonicus polysaccharide 


\subsection{Physicochemical properties of the polysaccharide}

Table 4. Result of physicochemical properties of L. japonicus polysaccharide

\begin{tabular}{cccccccc}
\hline $\begin{array}{c}\text { Colour } \\
\text { observation }\end{array}$ & Solubility test & $\begin{array}{c}\text { Phenol- } \\
\text { sulfuric test }\end{array}$ & Fehling's test & $\begin{array}{c}\alpha \text {-naphthol } \\
\text { test }\end{array}$ & $\begin{array}{c}\text { Carbazole test } \\
\text { FeCl test }\end{array}$ & $\begin{array}{c}\text { Coomassie } \\
\text { brilliant blue } \\
\text { test }\end{array}$ \\
\hline \multirow{2}{*}{ Brown } & Water & +ve & -ve & $-v e$ & $+v e$ & $-v e$ & $+v e$ \\
\hline
\end{tabular}

Note: +ve mean positive reaction and -ve means negative reaction.

According to Table 4, the physicochemical properties indicated that L. japonicus polysaccharide was brown in colour and water soluble. It can also be said that it was a non-reducing polysaccharide due to the result yielded by phenol-sulfuric test, fehling, and $\alpha$-naphthol. Result obtained by $\mathrm{FeCl}_{3}$ also indicated the absence of polyphenols in L. japonicus. Coomassie brilliant blue test and carbazole which both yielded positive value indicated the presence of protein and uronic acid in L. japonicus.

\subsubsection{DPPH Scavenging activity}

Figure 3 showed the scavenging activities of L. japonicas and Vit. C against DPPH radical. At a concentration of about $10 \mathrm{mg} / \mathrm{mL}$ to $100 \mathrm{mg} / \mathrm{mL}$, the DPPH radical scavenging activity of L. japonicus increased until the maximum value of $58 \%$ at $100 \mathrm{mg} / \mathrm{mL}$. The scavenging effect of L. japonicus was visibly not as strong as Vit. $\mathrm{C}$ as the maximum scavenging rate of Vit. $\mathrm{C}$ reached almost $96 \%$ at 100 $\mathrm{mg} / \mathrm{mL}$.

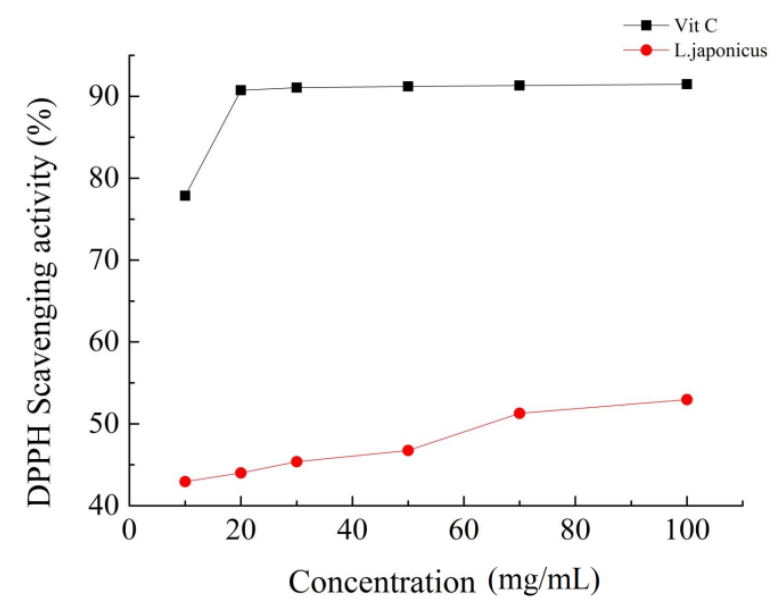

Figure 3. DPPH Scavenging activity of

L. japonicus polysaccharide

\subsection{Structural Analysis of L. japonicus polysaccharide}

\subsubsection{Scanning Electron Microscope (SEM)}

The Scanning Electron Microscope (SEM) is a type of electron microscope that enables a clear observation of very small surface structures, impossible with an optical microscope. In addition, it can engendered images with deeper focal depth and enable observations of 3-dimensional images, with a similar sense as looking at a substance with the naked-eye, by enlarging the specimen surface which has a rough structure. Although, the preparation of polysaccharide might have caused damaged to the sample, the result as underpinned by Figure 4 (A \& B) below showed that the microscopic conformation of L. japonicus polysaccharide after ultrasonic effect reflected a morphological characteristic of forming films without measurable and defined format. These micrographs was similar to that reported by Pan et al. [46] that studied the heteropolysaccharide of corn silk. They denoted that the pores presented in the sample was associated to the lyophilization process. 

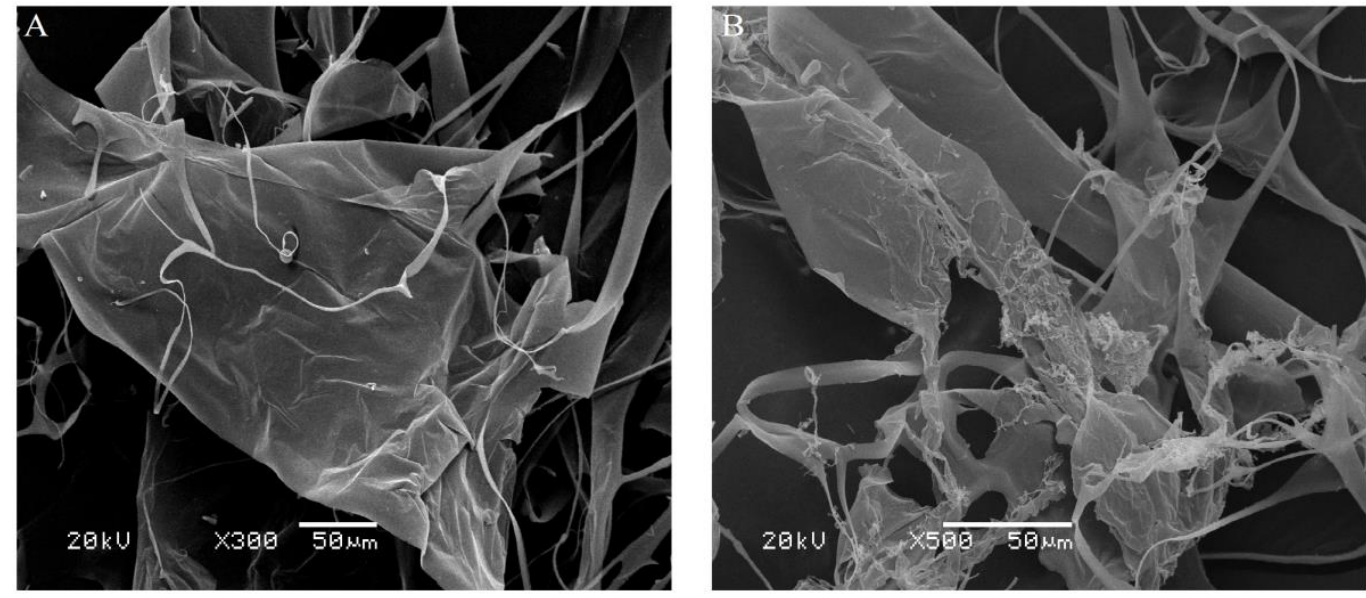

Figure 4. Scanning Electron Microscopy of L. japonicus polysaccharide with magnification of $\times 300$ and $\times 500$

\subsubsection{Atomic Force Microscopy (AFM)}

One of the ways to study the steric structure of polysaccharide is Atomic Force Microscopy. It is a novel type of scanning probe microscopy that generates images, primarily topographical ones, by scanning the surface of samples with a sharp tip attached to a cantilever [47]. As a result of this, it can be deduced that AFM generates images by having contact with the samples instead of observing them. The overall particle size of a sample can be known with AFM due to the AFM tip-broadening effect $[48,49]$. Figure 5 (A, B) showed the molecular morphology as analyzed by AFM with an area of $10 \mu \mathrm{m}$ by $10 \mu \mathrm{m}$, scan rate of $1.001 \mathrm{~Hz}$. The diameter of spherical lumps of $L$. japonicus polysaccharide was in the range of 70-300 $\mathrm{nm}$. AFM study showed that the polysaccharide from L. japonicus have a dotted-like structure scattered around the flatten surface of the image depicted by the Figure $5 \mathrm{~b}$ a below. Figure 5b. demonstrated the depth of field, and height of polysaccharides fibre relative to the background. These results underpinned $L$. japonicus polysaccharide had been having more than one chains which were branched and entangled with each other [49-55].
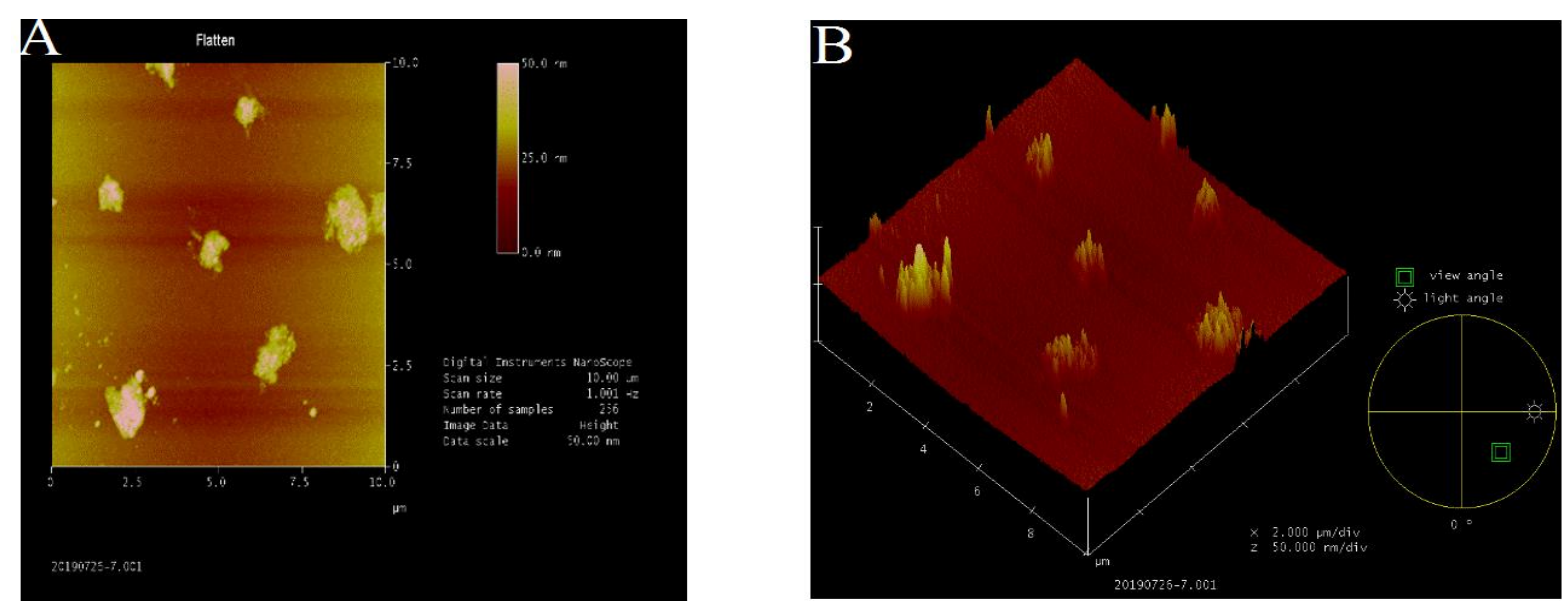

Figure 5. AFM image of L. japonicus polysaccharide (A and B: scan size $10 \mu \mathrm{m}$, scan rate $1.001 \mathrm{~Hz})$

\subsubsection{Fourier transform infrared spectroscopy (FT-IR)}

FT-IR principle works by detecting the band of organic matters present in the sample. The infrared spectrum (Figure 6) showed a board band wavelength overlap between the absorption of various components of the functional groups in the sample. $2925.64 \mathrm{~cm}^{-1}$ band indicated the presence of C-H stretching [56], this may be attribute to lipophilic components [57]. The peak at 1635.06 and 1539.73 
$\mathrm{cm}^{-1}$ indicated the presence $\mathrm{C}=\mathrm{C}$ stretching in aromatic system. Peak at $1635.06 \mathrm{~cm}^{-1}$ could also indicate bond of $\mathrm{N}-\mathrm{H}$ bend $/ \mathrm{C}=\mathrm{C}$ stretch. Indicative of $\mathrm{C}-\mathrm{O}$ stretch is peak at $1046.73 \mathrm{~cm}^{-1}$. The absorbance of the polysaccharide at $477.86 \mathrm{~cm}^{-1}$ can be assigned to skeletal modes of pyranose rings. The observed functional groups of $L$. japonicus polysaccharide as indicated by the Fig. 6 below mainly correspond to a good source of antioxidant [35, 36, 58-62].

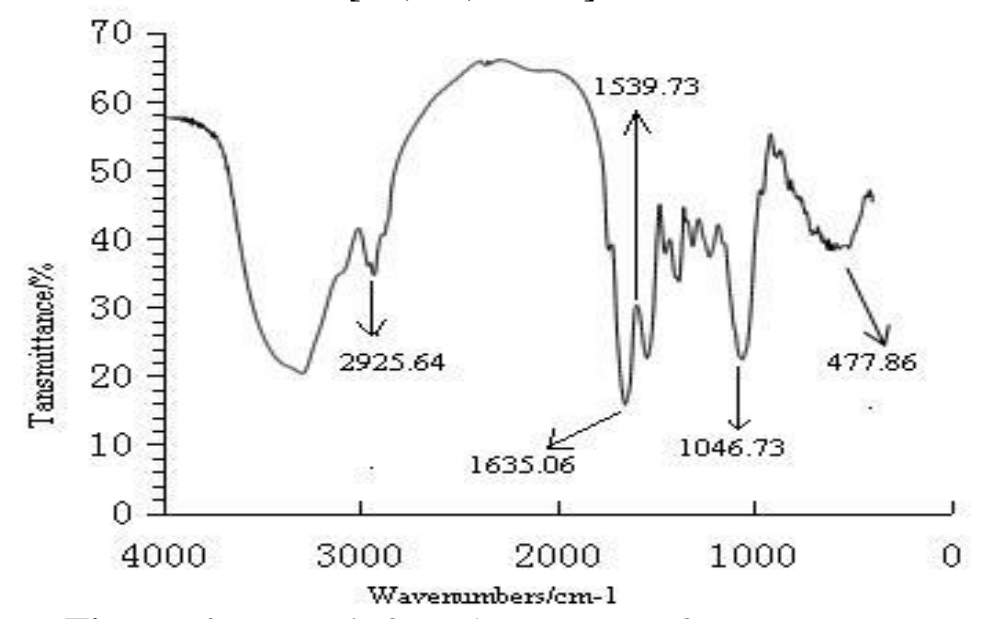

Figure 6. FT-IR infrared spectrum of L. japonicus

\section{Conclusions}

The three independent variables (extraction temperature, extraction duration and power) have significant effect on the yield of polysaccharide while the interaction effects of extraction time and ultrasonic power was more significant on polysaccharide yield. To optimize the extraction by ultrasonic technology, a second-order polynomial was applied. The optimum extraction conditions were: extraction time $50 \mathrm{~min}$, extraction temperature $70^{\circ} \mathrm{C}$, ultrasonic power $210 \mathrm{~W}$ and ratio of material to water 1:15. Under these sets of conditions, maximum value of polysaccharide yield was $11.64 \%$. This work provided an efficient method that can be used to extract water soluble polysaccharides from $L$. japonicus. The result of in vitro DPPH scavenging activity showed that polysaccharides can act as a natural DPPH scavenger. The results of the structural analysis using AFM showed L. japonicus polysaccharides have a dotted-like structure, scattered around the flatten surface of the image while that of FT-IR showed a broad band wavelength of 2925.64, 1635.06, 1539.7, 1046.73 and $477.86 \mathrm{~cm}^{-1}$, indicting L. japonicus polysaccharides to be a good source of antioxidant. Therefore, this study suggested that L. japonicus can play a vital role as a potential functional ingredient in food and medicines.

Acknowledgement. This study was financially supported by the National Natural Science Foundation of China (No. 81660581).

\section{References}

1.COMMITTEE FOR THE PHARMACOPOEIA OF P. R. CHINA., Pharmacopoeia of P. R. China, Part I. China Medical Science and Technology Press, P.R. China (in Chinese), 2010.

2.SHANG, X., PAN, H., WANG, X., HE, H., \& LI, M., Leonurus japonicus Houtt.: ethnopharmacology, phytochemistry and pharmacology of an important traditional Chinese medicine. J. Ethnopharmacol., 152(1), 2014, 14-32.

3.DENG, Z.G., Leonurus japonicus: women's good friend forever. Health Life, 20 (in Chinese), 2010. 4.PEKAL, A., BIESAGA, M., PYRZYNSKA, K., Interaction of quercetin with copper ions: complexation, oxidation and reactivity towards radicals, Biometals., 24(1), 2011, 41-49. 
5.LIANG, Y., LIN, Q., HUANG, P., WANG, Y., LI, J., ZHANG, L., CAO, J., Rice Bioactive Peptide Binding with TLR4 To Overcome H2O2-Induced Injury in Human Umbilical Vein Endothelial Cells through NF-кB Signaling. J. Agri. Food. Chem., 66(2), 2018, 440-448.

6.WANG, L., LIN, Q., YANG, T., LIANG, Y., NIE, Y., LUO, Y., LUO, F., Oryzanol modifies high fat diet-induced obesity, liver gene expression profile, and inflammation response in mice. J. Agri. Food. Chem., 65(38), 2017, 8374-8385.

7.LOU, Y., SHI, J., GUO, D., QURESHI, A. K., SONG, L., Function of PD-L1 in antitumor immunity of glioma cells. Saudi. J. Boil. Sci., 24(4), 2017, 803-807.

8.GUO, T., LIN, Q., LI, X., NIE, Y., WANG, L., SHI, L., LUO, F., Octacosanol attenuates inflammation in both RAW264. 7 macrophages and a mouse model of colitis. J. Agri. Food. Chem., 65(18), 2017, 3647-3658.

9.LI, W., JIA, M. X., WANG, J. H., LU, J. L., DENG, J., TANG, J. X., LIU, C., Association of MMP9-1562C/T and MMP13-77A/G polymorphisms with non-small cell lung cancer in southern Chinese population. Biomol, 9(3), 2019, 107-119.

10.NIE Y, LUO F, WANG L, YANG T, SHI L, LI X, SHEN J, XU W, GUO T, LIN Q, Antihyperlipidemic effect of rice bran polysaccharide and its potential mechanism in high-fat diet mice. Food. Func., 8(11), 2017, 4028-4041.

11.LOU, Y., YANG, J., WANG, L., CHEN, X., XIN, X., LIU, Y., The clinical efficacy study of treatment to Chiari malformation type I with syringomyelia under the minimally invasive surgery of resection of Submeningeal cerebellar Tonsillar Herniation and reconstruction of Cisterna magna. Saudi. J. Biol. Sci., 26(8), 2019, 1927-1931.

12.LOU, Y., GUO, D., ZHANG, H., SONG, L., Effectiveness of mesenchymal stems cells cultured by hanging drop vs. conventional culturing on the repair of hypoxic-ischemic-damaged mouse brains, measured by stemness gene expression. Open. Life. Sci., 11(1), 2016, 519-523.

13.CHEN, X., XU, Y., MENG, L., CHEN, X., YUAN, L., CAI, Q., SHI, W., HUANG, G., Nonparametric partial least squares-discriminant analysis model based on sum of ranking difference algorithm for tea grade identification using electronic tongue data identify tea grade using e-tongue data. Sens. Actuators. B. Chem., 2020, 127924.

14.NIE, Y., LUO, F., LIN, Q., Dietary nutrition and gut microflora: A promising target for treating diseases. Trends. Food. Sci. Technol., 75, 2018, 72-80.

15.REN, Y., JIAO, X., ZHANG, L., Expression level of fibroblast growth factor 5 (FGF5) in the peripheral blood of primary hypertension and its clinical significance. Saudi. J. Biol. Sci., 25(3), 2018, 469-473.

16.ZHU, Z.Y., LIU, R.Q., SI, C.L., ZHOU, F., WANG, Y.X., DING, L.N., JING, C., LIU, A.J., Structural analysis and anti-tumor activity comparison of polysaccharides from Astragalus, Carbohyd. Polym., 85, 2011, 895-902.

17.JIN, L., GUAN, X., LIU, W., ZHANG, X., YAN, W., YAO, W.B., GAO, X.D., Characterization and antioxidant capacity of a polysaccharide extracted from Sarcandra glabra. Carbohyd. Polym., 90, 2012, 524-532.

18.WIJESINGHE, W.A.J.P., ATHUKORALA, Y., JEON, Y.J., Effect of anticoagulative sulfated polysaccharide purified from enzyme-assistant extract of a brown seaweed Ecklonia cava on Wistar rats, Carbohyd. Polym., 86, 2011, 917-921.

19.RAYMOND, H AND DOUGLAS, C. Response Surface Methodology: Process and Product in Optimization Using Designed Experiments ( $1^{\text {st }}$ edition). John Wiley \& Sons, Inc. New York, NY, USA, 1995.

20.ZENG, L., CHEN, G., CHEN, H., Comparative Study on Flow-Accelerated Corrosion and Erosion-Corrosion at a $90^{\circ}$ Carbon Steel Bend. Materials, 13(7), 2020, 1780-1796.

21.CHEN, H., FAN, D., HUANG, J., HUANG, W., ZHANG, G., HUANG, L., Finite Element Analysis Model on Ultrasonic Phased Array Technique for Material Defect Time of Flight Diffraction Detection. Sci. Adv. Mater., 12(5), 2020, 665-675. 
22.CHENG, Y., SONG, Z., JIN, J., WANG, J., WANG, T., Experimental study on stress wave attenuation and energy dissipation of sandstone under full deformation condition. Arab. J. Geosci., 12(23), 2019, 736-749.

23.WANG, H., WANG, J., LU, H., BO, G., ZHANG, X., CAO, Y., LIU, L., ZHANG, J., ZHANG, $\mathrm{W}$., Analysis of coating electrode characteristics in the process of removing pollutants from wastewater. Fresenius. Environ. Bull., 29(2), 2020, 715-721.

24.DUBOIS, M., GILLES, K.A., HAMILTON, J.K., REBERS, P.A., SMITH, F., Colorimetric method for determination of sugars and related substances. Anal. Chem. 28, 1956, 350-356.

25.ZHANG, Q., ZHANG, T.M., Determination of polysaccharide content by phenol-sulfuric acid method. Shandong. Food. Sci. Technol., 13, 2004, 17-18.

26.MONTGOMERY, D.C., (2001). Design and analysis of experiments (5th new ed., pp.455-492). York: Wiley.

27.GE, Y., DUAN, Y., FANG, F., ZHANG, G.Z., WANG, Y., Polysaccharides from fruitcalyx of Physalis alkekengi var. francheti: isolation, purification, structural features and antioxidant activities, Carbohyd. Polym., 77(2), 2009, 188-193.

28.ARMAS, M., MALOLOT, R.D., DE CASTRO-CRUZ, K., Classification Test of Organic Compounds Using Preliminary and Solubility Test, 2006.

29.LIU, Y.M., QIAN, T.T., JIANG, D.W., HE, Y., SHEN, X.R., JIANG, S.Q., The comparison with Kjeldah and coomassie brilliant blue method on testing protein content of the polysaccharide from Sipunculus nudus. Chin. J. Exp. Traditional. Med. Formulae., 19(19), 2013, 96-98.

30.BITTER, T., MUIR, H.M., A modified uronic acid-carbazole reaction, Anal. Biochem., 4, 1962, 330-334.

31.ZHOU, K.Y. (1978). Organic Chemistry Experiment. Higher Education Press, Beijing, pp. 272.

32.MOHAMED, I.E., Laboratory Activities to Introduce Carbohydrates Qualitative Analysis to College Students. World J. Chem. Educ., 6(2), 2018, 82-86.

33.YAN, J. K., LI, L., WANG, Z. M., WU, J. Y., (2010). Structural elucidation of an exopolysaccharide from mycelial fermentation of a Tolypoclndium sp. fungus isolated from wild Cordyceps sinensis, Carbohyd. Polym., 79, 2010, 125-130.

34.HROMÁDKOVÁ, Z., EBRINGEROVÁ, A., VALACHOVIC, P., Comparison of classical and ultrasound-assisted extraction of polysaccharides from Salvia officinalis L, Ultrason. Sonochem., 5, 1999, 163-168.

35.CUI, F.J., QIAN, L.S., SUN, W.J., ZHANG, J.S., YANG, Y., LI, N., ZHUANG, H.N., WU, D., Ultrasound-Assisted Extraction of Polysaccharides from Volvariella volvacea: Process Optimization and Structural Characterization, Molecules., 23(7), 2018, 1706-1720.

36.WANG, J., ZHANG, J., ZHAO, B., WANG, X., WU, Y., YAO, J., A comparison study on microwave-assisted extraction of Potentilla anserina L. polysaccharides with conventional method: Molecule weight and antioxidant activities evaluation, Carbohydr. Polym., 80, 2010, 84-93.

37.HROMÁDKOVÁ, Z., EBRINGEROVÁ, A., VALACHOVIC, P., Ultrasound-assisted extraction of water-soluble polysaccharides from the roots of valerian (Valeriana officinalis L.) Ultrason. Sonochem., 9, 2002, 37-42.

38.LIU, Z., FENG, J., WANG, J., Resource-Constrained Innovation Method for Sustainability: Application of Morphological Analysis and TRIZ Inventive Principles. Sustainability, 12(3), 2020, 917-939.

39.WANG, M., ZHANG, D., CHENG, Y., TAN, S. K., Assessing performance of porous pavements and bioretention cells for stormwater management in response to probable climatic changes. $J$. Environ. Manage., 243, 2019, 157-167.

40.WANG, H., AN, X., ZHANG, Z., Effect of advanced treatment on ammonia nitrogen contained in secondary effluent from wastewater treatment plant. Fresenius. Environ. Bull., 27(4), 2018, $2043-$ 2050. 
41.WANG, H., ZHONG, H., BO, G., Existing forms and changes of nitrogen inside of horizontal subsurface constructed wetlands. Environ. Sci. Poll. Res., 25(1), 2018, 771-781.

42.QUAN, Q., HAO, Z., XIFENG, H., JINGCHUN, L., Research on water temperature prediction based on improved support vector regression. Neur. Comp. App., 2020, 1-10.

43.ZHANG, T., WU, X., SHAHEEN, S. M., ZHAO, Q., LIU, X., RINKLEBE, J., REN, H., Ammonium nitrogen recovery from digestate by hydrothermal pretreatment followed by activated hydrochar sorption. Chem. Eng. J., 379, 2020, 1-54.

44.SHUAI, Z., YAN-SHEN, C., The study of Hericium polysaccharide Dong-based enzymatic extraction, Henan University of Technology, 31, 2010, 76-79.

45.ZHENG, L., WEN, G., YUAN, M., GAO, F., Ultrasound-Assisted Extraction of Total Flavonoids from Corn Silk and Their Antioxidant capacity, J. Chem., 2016.

46.PAN, Y., WANG, C., CHEN, Z., LI, W., YAN, G., CHEN, H., Physicochemical properties and antidiabetic effects of a polysaccharide from corn silk in high-fat diet and streptozotocin-induced diabetic mice, Carbohyd. Polym., 164, 2017, 370-378.

47.FUNAMI, T., MAKOTO, N., SAYAKAISH, I., TAKAHASHIB, R., SAPHWAN, A., SHINYA, I., KATSUYOSHI, N., GLYN O.P., Molecular structures of gellan gum imaged with atomic force microscopy (AFM) in relation to the rheological behavior in aqueous systems in the presence of sodium chloride, Food. Hydrocoll., 23(2), 2009, 548-554.

48.TODD, B.A, EPPELL, S.J., A method to improve the quantitative analysis of SFM images at the nanoscale, Surf. Sci., 491, 2001, 473-483.

49.NASONGKLA, N., SHUAI, X.T., AI, H., WEINBERG, B.D., PINK, J., BOOTHMAN, D.A., GAO, J.M., CRGD-functionalized polymer micelles for targeted doxorubicin delivery, Angew. Chem., 116, 2004, 6483-6487.

50.WANG, P., LI, J. B., BAI, F. W., LIU, D. Y., XU, C., ZHAO, L., WANG, Z. F., Experimental and theoretical evaluation on the thermal performance of a windowed volumetric solar receiver. Energy, 119, 2017, 652-661.

51.LEI, Z., GAO, H., CHANG, X., ZHANG, L., WEN, X., WANG, Y., An application of green surfactant synergistically metal supported cordierite catalyst in denitration of Selective Catalytic Oxidation. J. Clean. Prod., 249, 2020, 1-26.

52.LEI, Z., JIHAO, C., ZHANG, L., HUIBIN, H., YUSU, W., YONGHUI, L., Preparation of soybean oil factory sludge catalyst and its application in selective catalytic oxidation denitration process. $J$. clean. Prod., 225, 2019, 220-226.

53.LEI, Z., YANG, J., HUIBIN, H., CHAO, Y., MIN, L., LINTIAN, M., Preparation of soybean oil factory sludge catalyst by plasma and the kinetics of selective catalytic oxidation denitrification reaction. J. clean. Prod., 217, 2019, 317-323.

54.YU, D., ZHU, H., HAN, W., HOLBURN, D., Dynamic multi agent-based management and load frequency control of PV/Fuel cell/wind turbine/CHP in autonomous microgrid system. Energy, 173, 2019, 554-568.

55.ZHU, B., YE, S., HAN, D., WANG, P., HE, K., WEI, Y. M., XIE, R., A multiscale analysis for carbon price drivers. Energy. Econ., 78, 2019, 202-216.

56.ZHANG, H., YE, L., WANG, K., Structural characterization and anti-inflammatory activity of two water-soluble polysaccharides from Bellamya purificata, Carbohyd. Polym., 81, 2010, 953-960.

57.PRASAD, A.G., KUMAR, J.K., SHARANAPPA, P., Fourier transform infrared spectroscopic study of rare and endangered medicinal plants, Rom. J. Biophys., 21(3), 2011, 221-230.

58.MAOBE, M., NYARANG, R., Fourier Transformer Infra-Red Spectrophotometer Analysis of Urtica dioica Medicinal Herb Used for the Treatment of Diabetes, Malaria and Pneumonia in Kisii Region, Southwest Kenya, World. Appl. Sci. J., 21(8), 2013, 1128-1135.

59.JORDAN, A.R., RACINE, R.R., HENNIG, M.J.P., LOKESHWAR, V.B., The role of CD44 in disease pathophysiology and targeted treatment, Front Immunol., 6, 2015, 182. 
60.LAGOURI, V., GULDAS, M., GURBUZ, O., In vitro antioxidant/free radical scavenging and antibacterial properties of endemic oregano and thyme extracts from Greece, Food. Sci. Biotechnol., 20(6), 2011, 1487-1493.

61.YANG, L., ZHANG, L.M., Chemical structural and chain conformational characterization of some bioactive polysaccharides isolated from natural sources, Carbohyd. Polym., 76(3), 2009, 349-361.

62.ZHANG, Z., LV, G., JIANG, X., CHENG, J., FAN, L., Extraction optimization and biological properties of a polysaccharide isolated from Gleoestereum incnrnntum, Carbohydr. Polym., 117, 2015, $185-191$.

$\overline{\text { Manuscript received: } 21.03 .2020}$ 